Complexity in higher education politics: bifurcations, choices and irreversibility

Kauko, Jaakko

2014

Kauko , J 2014 , ' Complexity in higher education politics: bifurcations, choices and irreversibility ' , Studies in Higher Education , vol. 39 , no. 9 , pp. 1683-1699 . https://doi.org/10.1080/03075079.2013

http://hdl.handle.net/10138/154437

https://doi.org/10.1080/03075079.2013.801435

publishedVersion

Downloaded from Helda, University of Helsinki institutional repository.

This is an electronic reprint of the original article.

This reprint may differ from the original in pagination and typographic detail.

Please cite the original version. 
This article was downloaded by: [University of Helsinki]

On: 04 May 2015, At: 05:01

Publisher: Routledge

Informa Ltd Registered in England and Wales Registered Number: 1072954 Registered

office: Mortimer House, 37-41 Mortimer Street, London W1T 3J H, UK

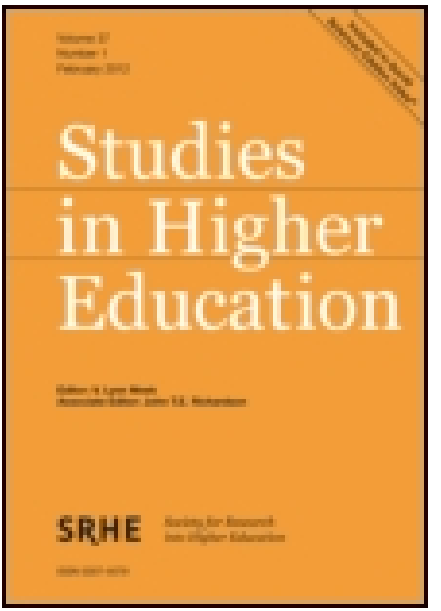

CrossMark

\section{Studies in Higher Education}

Publication details, including instructions for authors and subscription information:

http:// www.tandfonline.com/loi/ cshe20

\section{Complexity in higher education politics: bifurcations, choices and irreversibility}

\author{
J aakko Kauko ${ }^{a}$ \\ a Research Unit on New Politics, Governance, and Interaction in \\ Education (KUPOLI), Centre for Sociology of Education, PO Box 9 \\ (Siltavuorenpenger 3 A), 00014 University of Helsinki, Finland \\ Published online: 06 J un 2013.
}

\section{Click for updates}

To cite this article: J aakko Kauko (2014) Complexity in higher education politics: bifurcations, choices and irreversibility, Studies in Higher Education, 39:9, 1683-1699, DOI: 10.1080/03075079.2013.801435

To link to this article: http:// dx. doi. org/ 10.1080/03075079.2013.801435

\section{PLEASE SCROLL DOWN FOR ARTICLE}

Taylor \& Francis makes every effort to ensure the accuracy of all the information (the "Content") contained in the publications on our platform. However, Taylor \& Francis, our agents, and our licensors make no representations or warranties whatsoever as to the accuracy, completeness, or suitability for any purpose of the Content. Any opinions and views expressed in this publication are the opinions and views of the authors, and are not the views of or endorsed by Taylor \& Francis. The accuracy of the Content should not be relied upon and should be independently verified with primary sources of information. Taylor and Francis shall not be liable for any losses, actions, claims, proceedings, demands, costs, expenses, damages, and other liabilities whatsoever or howsoever caused arising directly or indirectly in connection with, in relation to or arising out of the use of the Content.

This article may be used for research, teaching, and private study purposes. Any substantial or systematic reproduction, redistribution, reselling, loan, sub-licensing, systematic supply, or distribution in any form to anyone is expressly forbidden. Terms \& 

and-conditions 


\title{
Complexity in higher education politics: bifurcations, choices and irreversibility
}

\author{
Jaakko Kauko* \\ Research Unit on New Politics, Governance, and Interaction in Education (KUPOLI), \\ Centre for Sociology of Education, PO Box 9 (Siltavuorenpenger 3 A), 00014 University of \\ Helsinki, Finland
}

\begin{abstract}
Taking complexity as an epistemic starting point, this article enhances understanding of dynamics in higher education. It also reviews the relevant literature on path dependency, complexity research, and studies of political change and contingency. These ideas are further developed with reference to the political situation and political possibilities as concepts. It is claimed that the key issues in understanding irreversibility on a system level are institutional change and politicisation. It is deduced from two case studies in the Finnish context that founding new institutions created bifurcations in both. Then again, the politicisation for disbanding existing institutions has proved rather futile. The key findings are that the choices in higher education politics increase the complexity of the system, and that many of the choices made are irreversible for reasons to do with contingency.
\end{abstract}

Keywords: complexity; dynamics; contingency; bifurcations; politics of education; institutional structure

\section{Introduction}

Ilya Prigogine (1997) claims that physics has neglected the arrow of time: the inevitable flow of time and the irreversibility of this process. According to him, classical and modern physics have both been unable to solve the paradoxes related to determinism. The first of these is that if everything is based on the classic laws of nature, everything becomes predetermined. Second, it is assumed in physics that the laws of nature work in both directions of time and thus embed reversibility. Prigogine convincingly argues a different stand and proposes 'new laws of nature' based on ideas of bifurcation and choice. These new laws seek a balance between the regularities and the contingencies of nature: "whether on the microscopic or macroscopic level, the new laws of nature deal with the possibility of events, but do not reduce these events to deductible, predictable consequences' (Prigogine 1997, 189). The types of irreversible process Prigogine is referring to include the thermodynamic increase in entropy, ageing and evolution. Prigogine's ideas are used in the social sciences specifically in research on complexities. Complexity refers to an epistemological choice presupposing unpredictable event progression with irreversible changes, and is influenced by the chaos theoretical paradigm (Capano 2009). In this article, presupposing complexity as the basic

\footnotetext{
*Email: jaakko.kauko@helsinki.fi
} 
condition of higher education systems, I aim to analyse two Finnish cases and at the same time test the ideas of Prigogine in this field.

Some recent research has focused on dynamics of interrelations in politics of education. D.B. Edwards (2012) is interested in formation of education reform agendas in the interactions of national and international organisations. On a national level, I have presented a model for analysing political dynamics in higher education politics (Kauko 2011a, 2013). The core idea in analysing dynamics is to focus on the attributes of interrelations rather than of actors (D.B. Edwards 2012, 129; Kauko 2013; see Emirbayer 1997). I develop this idea further in this article from the perspective of complexity through the conceptualisation of political contingency and focusing empirical research on different policy threads. Political contingency describes the room of action that different actors observe, shape and change (see Palonen 2003), whereas policy threads refer to the historical development of a problématique around a policy. Dynamics represent the theoretical tool that combines the other three concepts, analysing changes of contingency inside a complex system by focusing on policy threads.

The latest complexity-motivated qualitative studies in the field of education draw on either systems theory (Schriewer 2000; Medd 2002; Kiel 2006; Rasmussen 2010) or the actor network theory (ANT) (R. Edwards 2010; Fenwick 2010; I'Anson 2010). In terms of mapping complex developments, the concept of path dependency has also been discussed in the context of neo-institutional theories, for instance in relation to the seminal idea of increasing economic returns (Pierson 2000) and with regard to the lock-in effect of practices, behaviours and beliefs (Meyer 2011). There have been two main research strategies: mathematical formulas and computing, and qualitative approaches (Kiel 2006; Cilliers 2010; c.f. Medd 2002, 74). The latter reflects the focus of research discussed in this article.

Instead of trying to fit research designs from other fields, I consider Prigogine's ideas in a metaphorical sense and capitalise on interdisciplinary 'selective borrowing and mutual learning' (Wimmer 2006, 2; see Kiel 2006, 52-53). Accordingly, I build on ideas that are similar to Prigogine's notions of bifurcation and choice in studying change in higher education politics.

In the following I set the stage, relating earlier research on complexity to the conceptual view of contingency. I then introduce the three dimensions of contingency that could serve as a theoretical basis for understanding bifurcations and choices. Next I take the theoretical thinking closer to empirical understanding through the notion of path dependency and its contribution in analysing the irreversibility of changes in policy threads, and apply these ideas to an example of political dynamics in Finnish higher education. On the basis of an analysis of the empirical material I raise two specific theoretical questions: How can we detect bifurcation points and choices made inside a higher education system? Could this help in furthering understanding of the complexities and dynamics of higher education politics? These questions are addressed in the concluding section.

\section{Theoretical starting points for analysing complexity}

Complexity research shares the interconnected ideas of nonlinearity, partial determination, branching effects and irreversibility (Wimmer 2006, 8). These starting points also create some of the basic tensions within this line of research.

Nonlinearity means that the research does not comply with the traditional understanding of causality: on the one hand it emphasises a nonlinear and probabilistic 
event progression and on the other aims at explaining patterns that do not have a single cause (Wimmer 2006, 2; R. Edwards 2010, 69). For instance, the complexivist perspective on the politics of education shares the premise that 'it is actually the emergence of order and predictability that requires explanation' (Biesta and Osberg 2010,2). Explaining order and patterns does not let complexity researchers off the hook in that they have to tackle the same problem of determinism as Prigogine (1997) pointed out. The question is simply put: if there are observable patterns in interrelationships, does it always affect the outcome in the same way? Is the course of events predetermined from the beginning?

In dealing with the problem of determinism researchers have coined the term 'bifurcation points', which is essential in understanding the changes creating the various branches of history. This is connected to the instabilities of the system. Medd (2002, 78), for instance, emphasises the need to understand emergence, which is dependent on the differences between the system and its environment. Bifurcation, preceded by instability in the system and the choices made at the bifurcation point, can be analysed afterwards once the chosen path becomes visible, as Biesta $(2010,12)$, drawing on Prigogine (1997), proposes. ${ }^{1}$

Osberg $(2010,160)$, using the ideas of Rancière (2010), further develops this idea in claiming that the bifurcation points are moments of forced decision-making: "we have to choose because we cannot go in two directions at the same time' (original emphasis). The choices made at moments of change are not based on reason, but are made on political grounds (Osberg 2010, 160). According to Medd (2002, 79), they are always 'contingent for they could have been otherwise.' In addition, as Weick, Sutcliffe and Obstfeld (2005) point out in coining the term sensemaking, the choices made may seem relevant only after the action: during the choice-making it is impossible to know the exact consequences. In conclusion with regard to the problem of determinism, I claim that at certain points of history an education system is faced with moments of change, but the outcome is not predetermined in that these moments as well as the choices made are contingent. Thus it is necessary to work for a deeper understanding of contingency.

Another contentious discussion concerns choices and power in a complex system: what are the relations between institutional and system-level practices and the individual? As Biesta $(2010,7)$ suggests: 'The important question complexity thus helps us to ask is how in a complex "universe" it is possible to achieve a reduction of complexity. Particularly with regard to social reality it also helps us to ask who is actually reducing complexity for whom and whose interests are at stake or being served by doing so.' In this vein, reducing complexity means limiting the possibilities of political action (see e.g. Bachrach and Baratz 1962, 1963; c.f. D. B. Edwards 2012). Although this could be a useful starting point for research, the notion of reducing complexity may be open to some critique and thus needs to be further developed. The question of 'whose interests are at stake' echoes the categories in the classical pluralist view of power: it is thus in conflict with the dynamic perspective, which shares a relativistic view (Emirbayer 1997; Kauko 2011b). In addition, actions reducing complexity are impossible in that they actually increase it from both the Luhmannian (Rasmussen 2010, 15) and the ANT perspectives (Fenwick 2010, 62). All in all, if we understand power to exist in the interactions of actors, that is, dynamics, it is epistemologically inconsistent to search for actors who could exercise their power in order to reduce complexity.

R. Edwards $(2010,71)$ suggests an interesting change of view, which could help to overcome the question of complexity reduction: 'It is rather that invention [in a 
contingent situation] entails a different configuration of relationship - of recursivity and reduction in complexity terms, and of purification and translation in ANT terms'. The way I understand this is that in referring to complexity reduction, Edwards is actually talking about the reorganisation of contingency. There is reference not to the interests of actors, but rather to the redefinition of relations, which is more consistent given the underlying assumptions of power. Hence, both the notion of complexity reduction and the perspectives of the actor could be better described through the concept of contingency.

In sum, I argue that in a complex political situation the main questions have to do with the organization and reorganization of contingency. At certain points an educational system, institution, organisation or person arrives at a bifurcation point at which it is necessary to make choices that are irreversible. These decisions determine the further course of the whole system and, respectfully, limit and make possible the dynamics in which it may work.

\section{Dynamics in the three dimensions of contingency}

Palonen (2006) in his vast conceptual history project distinguishes three clusters ${ }^{2}$ on the theme of 'politics': prudence and policy, commitment and contestation and, obviously the relevant one for this paper, contingency. The contingency cluster comprises the dimensions of situation, possibility and play \& game. By developing this idea further it is possible to form a basis on which to analyse contingency. The questions posed below embed the general ideas behind the tracing of dynamics (Table 1).

(1) Politics as a situation connotes the idea of an opportune moment, or kairos, when politics can be changed and when a historical rupture is visible. In order to make a change the actors have to notice the kairos, or make a radical reinterpretation in order to form such a moment (Palonen 2006). The Hellenistic sculptor Lysippos portrayed Kairos as a human-like flying creature with a long forelock and a bald occiput. The momentary nature of seizing the day, grabbing Kairos by the hair, is stated in the epigram on the statue: "none whom I have once raced by on my winged feet below will now, though he wishes it sore, take hold of me from behind' (Capps, Page and Rouse 1918, XVI, 275). The metaphor also implies that one choice is to let the Kairos fly away (c.f. Osberg 2010, 160). In an empirical sense, studying the political situation would mean scrutinising the appearance of bifurcation points in different

Table 1. A framework for the analysis of dynamics in politics (adapted from Palonen 2006; Simola 2011; Kauko et al. 2012).

\begin{tabular}{lcc}
\hline Dimension & Questions & Key focus of analysis \\
\hline $\begin{array}{c}\text { (1) The political } \\
\text { situation }\end{array}$ & $\begin{array}{c}\text { What is opportune in a specific socio- } \\
\text { historical and trans-national situation? }\end{array}$ & $\begin{array}{c}\text { Policy threads and their } \\
\text { path dependences }\end{array}$ \\
$\begin{array}{c}\text { (2) Political } \\
\text { possibilities }\end{array}$ & What is politicised and what is not? & $\begin{array}{c}\text { Politicisations and their } \\
\text { discursive formations }\end{array}$ \\
$\begin{array}{c}\text { (3) The political } \\
\text { Spielraum } \\
\text { (politicking) }\end{array}$ & $\begin{array}{c}\text { How do the relevant actors capitalise on } \\
\text { the existing situations and possibilities? }\end{array}$ & $\begin{array}{c}\text { Political action and its } \\
\text { ramifications }\end{array}$ \\
\hline
\end{tabular}


policy threads and the limitations they impose on political action. (Table 1, first row.)

(2) Politics as a possibility concerns the different alternatives that actors see, create and use in different situations (Palonen 2006, 237). Possibilities are created through politicisation, the reinterpretation of some issue as a conflict or the reorganisation of the conflicts at hand (Palonen 1993, 2003). In this sense, politicisation shapes the way contingency is understood, and opens up new ways of understanding the political situation and the discursive space. Indeed, when connected to the history and formation of subject positions, it is very close to the idea of discursive formations (Simola 1995). Thus it shapes the course of a certain policy thread and presents the choices to be made. Theories of the policy process have also tracked the birth of politicisation. Kingdon (2003), for instance, explains this process in terms of three different streams: problems, politics and policies (see Corbett 2005; Kauko 2013). A politicised possibility arises when these three streams are connected. Removing politicised possibilities, or depoliticising, is very difficult (see Palonen 1993), which connects political possibility to the idea of bifurcation. Once the choice has been made there is no going back. Politicisation removes the innocence of any given matter. (Table 1, second row.)

(3) Politics as a Spielraum. Politicking comes into play when a political question is open. It is the most restricted dimension of the ones analysed because it can function only inside the 'games' politicisation creates (Palonen 1993, 11). ${ }^{3}$ The use of the Spielraum is the concrete way in which choices are made in everyday life, and the focus in analysing it has to be on political action. It is thus different from the other two dimensions. Although restricted by the other dimensions, its practices can vary so much that it seems that the only criterion for finding politicking is to concentrate on analysing the acts of policy-making and its effects on politicisation and the political situation. (Table 1, third row.)

\section{Path dependency and policy threads}

Analysis of political contingency has produced three dimensions on which to understand bifurcations and choices, but the problem of how to determine the essential ones remains. Ex post, this type of question is a non-issue in part, a case of rationalisation (Castaldi and Dosi 2006, 115) or sensemaking (Weick, Sutcliffe and Obstfeld 2005). It is possible, at least in theory, to trace the key choices that have led to the chosen path. However, it may well be the small choices that are more important in its formation (Pierson 2000). Ex ante, the question is thornier. Could we detect the current bifurcation points in current politics or even predict future ones? Without further empirical work I am not going to give an answer to this latter question. (See Ma 2007, 71.) Not all choices create bifurcations or have an impact on the higher education system, but how can we understand which ones do? This is also connected to the idea of kairos: How do we understand the presence of such a moment? Theories of path dependency give good reference points for this type of reasoning.

Capano $(2009,25)$ aptly notes that the 'real hidden feature of path dependency frameworks is that they belong to the chaos and complexity epistemological perspective' especially through the notion of increasing returns (Pierson 2000). Path dependency 
implies contingency and the irreversibility of the process. Nevertheless, path-dependent frameworks also struggle with problems of over-stability as they leave little room for actors. It could be argued that irreversibility is a poor start to the analysis of politics, in which all decisions can be cancelled (Capano 2009, 25). The emphasis on structure also tends to lead to a situation in which change is explained in terms of exogenous shock (Pierson 2000, 265). A possible view on this is Knill and Lenschow's (2001, 198) suggestion of adaptational discretion, which is a combination of the political challenge posed and how it relates to existing structures. This type of thinking could enhance understanding of why some exogenous inputs seem like shocks and why some have no effect.

In drawing these theoretical considerations together a good starting point for analysing path dependency would be the conceptualization of contingency and seeking an understanding of how endogenous and exogenous factors interact. The result could be a clearer conception of the conditions under which bifurcations and path dependences are created.

I have noticed in different theories of the policy process and agenda setting in higher education that a kairos is frequently perceived at moments when the external factors of the system are in line with the internal institutional structure, and thus the political situation is understood to be a result of interplay between two factors: the institutional framework and the external socio-historical context (Sabatier 1987, 1993; Richardson et al. 1999; Bleiklie, Høstaker and Vabø 2000, 307; Kogan and Hanney 2000, 267237; Badat 2009; Baumgartner and Jones 2009). Vice versa, if the institutional framework within the education system is not compatible with the external factors, the political situation is unfavourable to change. ${ }^{4}$

I argue that the most important irreversible actions on the system level have to do with changing institutions and bringing about new politicisations. Of course, it could be argued that institutions can go back to where they were. However, I am sceptical about the idea that institutional changes could be subjected to rational policy-making and thus happen according to pre-set preferences. In addition, any substantial institutional change leaves its mark even if it means seemingly going back and forth. From the perspective of path dependency, a bifurcation moment always has some influence on the institutional structure: institutions are, after all, its very source (Ma 2007, 64). In order to identify such path dependency, in the following I suggest focusing on a limited number of policy threads that deal with the key problematics of a system.

\section{Two cases of path dependency, contingencies and shifting dynamics}

For the purposes of empirical illustration I exemplify dynamics through the case of Finnish higher education. The research material is from the project Power, Supranational Regimes and New University Management, ${ }^{5}$ which scrutinises higher education politics in Finland. As part of the project I analysed 25 interviews ${ }^{6}$ with minister-level politicians, ministry officers, university rectors and different stakeholder representatives (e.g. interest groups, labour unions and research funders), and analysed a corpus of 132 documents (Kauko 2011a, 2013).

For this study I used two dimensions of dynamics: the political situation and political possibilities; the third dimension, politicking, is only implicitly present (Table 1). The two dimensions form four different types of dynamics in education politics, as shown in Table 2. The first of these is reform, meaning that the political situation favours change, and that the politicised possibilities support it (Table 2, lower-right 
Table 2. Dynamics in higher education politics (DHEP) and the Finnish policy threads (Kauko 2013).

\begin{tabular}{|c|c|c|}
\hline & $\begin{array}{l}\text { The political situation is } \\
\text { unfavourable to change }\end{array}$ & $\begin{array}{c}\text { The political situation is favourable } \\
\text { to change }\end{array}$ \\
\hline $\begin{array}{l}\text { The political } \\
\text { possibilities are } \\
\text { settled }\end{array}$ & $\begin{array}{c}\text { Friction dynamics/governance } \\
\text { policy thread } \\
\text { Separation of budgetary means } \\
\text { and political ends in the } \\
\text { governance policy thread }\end{array}$ & $\begin{array}{l}\text { Consensual-change dynamics/ } \\
\text { international policy thread } \\
\text { The pragmatic and selective } \\
\text { infiltration of international influences } \\
\text { into national policy making }\end{array}$ \\
\hline $\begin{array}{l}\text { The political } \\
\text { possibilities are } \\
\text { politicised }\end{array}$ & $\begin{array}{c}\text { Gridlock dynamics/regional } \\
\text { policy thread } \\
\text { Gridlock in ministry } \\
\text { politicisation and provincial } \\
\text { representation }\end{array}$ & $\begin{array}{c}\text { Reform dynamics/research policy } \\
\text { thread } \\
\text { Enhancing innovation policy }\end{array}$ \\
\hline
\end{tabular}

cell). The second is gridlock, when there are politicised possibilities but they prove futile because the political situation does not allow change (Table 2, lower-left cell). Thirdly, in the case of consensual change the political situation favours change but there is no politicisation in terms of why it happens in a routine manner (Table 2, upper-right cell). The fourth type is the dynamics of friction, which cause inertia in the whole system when the situation does not favour change and there are no politicised possibilities (Table 2, upper-left cell) (Kauko 2013).

I first considered the documentary and interview material with a focus on the relations between the actors, and identified four central policy threads in the whole higher education system. After reanalysing the material paying attention to the patterns in the threads I was able to combine my observations in a theoretical model that identified the major aspects of the dynamics: reform of the research policy, gridlock in the regional policy, consensual change in the international policy and friction in the governance policy (Table 2). Finally I looked for conflicting views in the research material in order to test my conclusions.

As Table 2 indicates, inherent in the Finnish case are four independent policy threads, each illustrating one form of dynamics. Given the aim of this paper, I do not deal with settled policy threads, which I have illustrated in more depth elsewhere (Kauko 2011a, 2013; Table 2, top row). It is enough to mention the observation made during the research that, following structural adjustments to the system that made the situation favourable, international influences were imported into Finnish higher education policy-making in a pragmatic and routine, non-politicised way, mainly by officials rather than politicians. In the governance policy thread, which is not in focus here either, a friction in the higher education system was observable in the non-politicised separation of budgetary means and political ends: the tight budgetary framework and locked-in government programme on the state level, and the concentration on funding in the ministry-university negotiations made it really difficult to discuss budget and policy at the same time.

Rather than focusing on these developments, in the following I concentrate on two cases in Finnish higher education politics, which relate to the dynamics of gridlock and reform (Table 2, lower row). The biggest difference in these two threads, according to the model, should be in the favourability of the political situation, and the similarity should be that both are politicised and thus have the potential to generate conscious 
changes in policy-making. In other words, the decisions made in the course of history have determined the relationship between the institutional structure of the higher education system and its external factors (the political system and socio-historical developments). In concentrating on these two policy threads I hope to further understanding of the irreversibility or reversibility of institutional changes and the bifurcations they create.

\section{Gridlock in regional politics}

The first institutional changes in regional politics were made before and during the early years of Finland's independence (in 1917) when the quarrel between Swedish and Finnish speakers led to the founding of different universities for the two language groups in the core regions of Turku and Helsinki (Kivinen, Rinne and Ketonen 1993, 17; Pernaa 2007, 64). Before the Second World War all Finnish universities were concentrated in these two areas.

Later on, in Finland as in many other European countries higher education experienced a period of massification and regional expansion from the 1960s until the 1980s. The process continued with the creation of a binary structure when polytechnics (ammattikorkeakoulu) were established in the 1990s. A more recent development was the dissemination of so-called university centres, or 'satellites', around the country in the 2000s. As a result, in $200161.6 \%$ of municipalities had local access to higher education (Välimaa 2001,31). One of the interviewed politicians considered the expansion decisions necessary but acknowledged that it exerted 'structural pressure' on the whole system. According to another politician, university centres 'mushroomed without control' when politicians started to demand them for their home region. The interviewees considered the founding of new institutions easier than decreasing the numbers given their importance for the different regions.

After the expansion there were two counter waves: the first was during the economic recession of the 1990s and the second was in the beginning of the 2000s during an economic boom. The Ministry of Education initiated both waves, the purpose being to refocus the higher education system and create a clearer profile for different institutions (see Kivinen, Rinne and Mäntyvaara 1990). This project was given the bureaucratically diminutive name of 'structural development' (Opetusministeriö 1989). My focus in this text is on the latter wave, which was fresher in the memories of the interviewees, and also seemed to be more relevant than the first one, which died out after the recession (see Vanttaja and Ketonen 1995).

A significant politicisation event was the backing of Ministry of Education regional demands for the first time by the Science and Technology Council, the main higher education policy-coordinating organ (Opetusministeriö 1998; Valtion tiede- ja teknologianeuvosto 2000, 2003; Kauko 2011a, 94-95). A further boost came from the government's decision to start a wide-ranging productivity programme aimed at reducing the amount of public-sector personnel (Valtioneuvosto 2004). Finally, a Ministry of Education programme was set up to financially support the amalgamation of universities, and succeeded in catalysing three 'spearhead' projects in 2006-2007 (Opetusministeriö 2006, 2007, 2008).

One of the spearhead projects, the creation of Aalto University, a new foundation type of institution, in the capital region by combining three universities, was an especially contentious issue at the time of the interviews. It attracted criticism among the interviewed rectors, and was also hotly debated in the public realm. From one 
perspective this was a major shift in policy, concentrating more resources in the metropolitan area. Another view was that providing additional financial support for Aalto gave it an unfair competitive advantage.

Despite the criticism, government implemented the projects as part of the large reform package connected with the new universities act (Yliopistolaki 558/2009). However, the public dispute found its way to the legislative process before the law came into force when the Parliamentary Committee for Constitutional Law (2009), a political organ responsible for the ex ante constitutional evaluation of laws, questioned the setting up of a foundation-based university with only external board members, as would have been the case in Aalto University (see Kauko and Diogo 2011, 125-26). The compromise reached was to alter the law to require a majority of internal board members. Had the committee taken a stricter stand, the result might have been different.

According to the interviewees, the main driving force behind this latter wave was international competition. The intended structural changes were considered crucial. Despite the politicisation of the allegedly over-sized higher education system, the decision-making was very difficult for politicians and the different stakeholder organisations that had to make internal decisions or public announcements regarding regional issues.

The main reason why the decision-making was so difficult derives from the regional representation in the political system: members of parliament are also considered to be representatives of their region. For instance, one politician described speaking about reducing spending on university education as 'regional-political suicide'. The ministries were also aware of the politicians' attitudes.

The structural development is as difficult as always. Politicians say that it should be continued, but nothing can happen against the will of the universities and it cannot touch the politicians' regional university. (Officer)

Another feature of the political culture, continuity, has been delaying political decisions. Normally in the Finnish system two of the major three parties form the core of the government. This makes radical change difficult in that at least one of the parties has been involved in policy formation in earlier governments (Kauko 2011a, 152-54). However, the rise of a populist party in the 2011 parliamentary elections almost broke this pattern, but due to the novelty of the phenomenon it is too early to draw conclusions.

A whole new chapter started when the new university act was implemented. It released universities from the grip of the state and gave them more autonomy in terms of becoming private foundations or public non-profit corporations (Yliopistolaki 558/2009). Following this new autonomy there have been hints of regional concentration and the reduction of personnel in some universities, but the major trajectory is still unclear in terms of whether this marks a new bifurcation.

Most likely the trimming will happen in the next few years with regard to the university satellites in different municipalities, spurred on by the Ministry of Education funding policies. (Rector)

Above I claim that gridlock happens when there are politicised possibilities but they prove futile because the political situation does not allow change (Table 1). The combination of a political system based on provincial representation, a regional higher education institutional framework and international pressure to streamline the structure created an unfavourable political situation in the regional policy thread. Although 
officers in different ministries had been politicising possibilities for decades with a view to downsizing the higher education system (see Ursin, Välimaa and Aittola 2010, 2011), these efforts did not have much effect due to provincial pressure on politicians. In the end, the spearhead projects also sustained most of the old structures. The existing institutional structure proved to be the main explanation for the non-existing change: it effectively blocked active attempts at regional redistribution.

In terms of path dependence and bifurcation points in history, the building of a regional university system is a strong example. This branch of the path was sustained and it also set the scene for the future politicisation of 'structural development'. No university has been disbanded in the history of independent Finland. This shows strong continuity and difficult reversibility. Even though the bureaucrats and some politicians would have liked to trim the higher education system it seemed very difficult. Thus, even if one accepts that political decisions can be reversed, even in a very concrete sense as in the case of the parliamentary committee, it is a very difficult process once an institution has been founded and the whole institutional framework has changed accordingly. The latest changes in legislation, and possibly in political consensus, could nevertheless provoke an endogenous change.

\section{Research politics in reform}

Before the massification of Finnish higher education, research and development took place in two settings: universities and research institutes, and laboratories connected with major industry (Michelsen 1990; Tiitta 2004). As the university sector expanded the technology side grew even more strongly, which hallmarked the biggest change in research politics during the 1970s and 1980s (Kivinen and Rinne 1992). In fact, the funding for these two areas became more or less even. This change was facilitated through changes in the institutional structure, which strengthened the role of the Ministry of Trade and Industry in relation to the Ministry of Education. The most significant developments were the boost in funding during the 1970s and the foundation of the Finnish Funding Agency for Technology and Innovation in 1983. At the same time, the main resource for basic research, the Academy of Finland, started show interest towards technology (Immonen 1995).

The institutional change of encouraging technology research was concretised in the main policy-negotiating organ when the former National Science Council was renamed the National Science and Technology Council (Valtion Tiede- ja teknologianeuvosto 1987). The Council was also responsible for the major decisions aimed at enhancing innovations, coining the term 'National Innovation System' during its first years of operation to describe the whole higher education system (see Miettinen 2002). This perspective was also strongly connected to the idea of economic gains of research (Valtion tiede- ja teknologianeuvosto 1990). From the perspective of one interviewee (Stakeholder), the idea of a national innovation system gained momentum in that it was connected to the recovery after the depression of the 1990s.

The Science and Technology Council rather consistently developed policy tools for enhancing innovation-oriented research, and so-called basic research was given less attention (Valtion tiede- ja teknologianeuvosto 1993, 1996). This was reflected in the Academy of Finland, which had reformed its structure during 1993-1995 and was more ready to give out statements. While the Science and Technology Council and the different governments continued on the path of highlighting the importance of innovations, the Academy of Finland started to question, with 
increasing concern, the extent to which the National Innovation System supported basic research (Kauko 2011a, 83).

The innovation policy culminated in the amalgamation of the Ministry of Trade and Industry with parts of other ministries, and the establishment of a new 'super ministry' in the form of the Ministry of Employment and Economy in 2008 (Työ- ja elinkeinoministeriö 2008). The founding of the new ministry was written into the programme of the coalition government headed by the Centre Party (Government Programme 2007). There were two significant developments assisting this process. First, the interviewees recognised the central role of two prominent figures from the Prime Minister's party as catalysts, and second, the Ministry of Trade and Industry had started to promote this option for the government programme (Kauppa- ja teollisuusministeriö 2006).

According to a stakeholder interviewee, the new ministry instantly took a visibly expansive role in innovation policy. The Academy of Finland sharply criticised the policies that motivated the founding of the new ministry:

The most important policy documents of recent years - have locked scientific research into the context of technology and the economy, which does not sufficiently take into account the importance of basic research and plurality in innovation activities. (Suomen Akatemia 2009, 248)

The polarisation was evident as the interviewees identified two coalitions in the institutional structure: the innovation coalition and the basic research coalition. The former comprises the Ministry of Employment and Economy, the funding organisations of innovation and technology research and possibly the Ministry of Finance, and the latter includes the Academy of Finland, the Ministry of Education and Culture, and at least some of the larger universities. As noted above, more politicised possibilities were created favouring innovation activities over basic research.

In Table 2 I refer to the dynamics of reform, meaning that the political situation favours change, and that the politicised possibilities support it. The Finnish researchpolicy thread functions accordingly. The political situation has been very favourable to research-policy change with an emphasis on innovation. A long-term conceptual push for a national innovation system was responsible for most of the groundwork, and the idea was solidified as the system was considered the main reason for Finland's emergence from the economic depression of the 1990s. It was manifested in multiple changes in the institutional structure, and at the same time the politicisation reflected the divide between basic research and research supporting technology and innovation.

The main exogenous factor was the economic depression at the beginning of the 1990s (see Välimaa 2012) and the national survival story. This created the political plot for the following decades. Endogenous, institutional changes happened incrementally, the most far-reaching of which were the founding of the Finnish Funding Agency for Technology and Innovation (in 1983) and the Ministry of Employment and Economy (in 2008). Establishing these institutions could be considered significant bifurcations within this policy thread.

Nevertheless, the founding of the ministry was a contingent event, just one possible branch in a complex entity. It was pushed forward strongly by policy-makers at an opportune moment during the change of government, when there was politicisation in the sphere of innovation policy. The moment and the power of the policy-makers were dependent on the election result at least, but then again the groundwork done by the Ministry of Trade and Industry helped. 
In the case of regional politics the institutional choices restricted the area of politics, whereas it was the opposite in the case of research politics: the political push for innovation gradually reshaped the institutional structure. Research politics is a good example of a path-dependent trajectory that changes track little by little as a result of contingent exogenous and conscious endogenous changes.

\section{Conclusions}

Complexity is more of an epistemological starting point than a mere theoretical concept. The key question is this: Does complexity bring new insights to the phenomenon in question? At the beginning of this article I presented a framework for understanding the complexities and dynamics of higher education politics based on a theoretical understanding of bifurcation and choices.

Both important bifurcation factors were present in the two empirical cases presented: politicisation and the creation of new institutions. In the case of regional politics the institutions were created over a relatively long period and their reformation seemed really difficult, whereas in research politics the politicisation provoked their creation. This observation supports the notion of changes in institutions as bifurcation points: founding new ones created path dependency in both cases. Then again, the politicisation regarding the disbanding of existing institutions proved rather futile, but in any case seemed really persistent.

On a more substantial level, both cases support the interpretation from earlier research findings suggesting that an opportune moment needs aligned external and internal factors - in this case of the higher education system. An interesting question regarding endogenous change will arise in the regional policy thread after the new university law starts to take effect. The more autonomous universities could instigate more radical changes even without an external push. In line with the idea that institutional change indicates bifurcation, it could be claimed that the new university law has created a new bifurcation point in regional policy, but the course of this path is still contingent.

The empirical conclusions failed fully to clarify some issues regarding the role of bifurcation points. It was evident that certain choices made concerning the institutional structure had an impact in creating favourable or unfavourable surroundings inside a policy thread. The analysis does not fully reveal whether or not such choices were forced, as Osberg (2010) claims, drawing on Ranciére (2010). For instance, many of the choices regarding institutions were also contingent in that it is easy to see how they could have been otherwise, but it is another question whether retaining the status quo is also a choice. All in all, the most important idea from the dynamics perspective is that different actors are relevant to different policy threads (Kauko 2013). In order to be able to grab the forelock, the grabber needs to be within reaching distance, and to be included in the game.

As suggested, the idea of reducing complexity is perhaps not the best possible way of understanding the changes in the empirical material mentioned above. For example, it is easy to see how the new institutions in Finnish higher education reorganised contingency, in the research-policy case after having reshaped what were desirable actions in the field. Moreover, the politicisation in terms of understanding the national innovation system triggered many changes in the institutional structure. It could even be claimed that the government programme in the case of research policy was a main simplifying factor, setting the agenda for future years. However, I would be wary of 
claiming that these attempts reduced complexity. It could rather be said that the institutions fostered chaos: new political quarrels, new policy tools for innovation and a more complex institutional structure. Once a new institution or initiative is introduced, the innocence of a policy thread is lost. This was the case, for instance, in the pertinent politicisation and the even more pertinent institutions in the regional policy thread. The ever-increasing complexity makes it hard to argue for reversible choices. In this sense, and given the epistemological choice of complexity, Prigogine's arrow of time also seems to offer the potential for further theorisation in the politics of higher education.

\section{Acknowledgements}

The author has benefited from the Funding of the Academy of Finland in terms of the projects Power, Supranational Regimes and New University Management (2007-2010) and Expanding the Theoretical Frontiers - Contrasting the Dynamics in Education Politics in England and Finland (2012-2015).

\section{Notes}

1. More relaxing and uncritical reports of bifurcations appear in popular culture. The film Sliding Doors (1998) presents two possible event progressions based on whether the main character catches a train. A more complex example of branching paths is to be found in the novel (1999, Robert J. Sawyer) and the TV series Flash Forward (2009).

2. The theme of 'irregularity' is not among the clusters, although it is a conceptual aspect of politics (Palonen 2006).

3. For policy-makers, the restrictions are even visible in understanding politics to happen in a 'piecemeal and pragmatic fashion' (Bird 1994, 83).

4. This is different from Becher and Kogan's (1992) model in which the delineation of norms and operations catalyse change. Becher and Kogan's idea actually comes close to the idea of how politicisation is understood in this paper.

5. Funded by the Academy of Finland.

6. I conducted the interviews together with Risto Rinne and Hannu Simola, who were the responsible leaders of the project.

\section{References}

Badat, S. 2009. Theorising institutional change: post-1994 South African higher education. Studies in Higher Education 34, no. 4: 455-67.

Bachrach, P, and M.S. Baratz. 1962. Two faces of power. The American Political Science Review 56, no. 4: 947-52.

Bachrach, P, and M.S. Baratz. 1963. Decisions and nondecisions: an analytical framework. The American Political Science Review 57, no. 3: 632-42.

Baumgartner, Frank R., and Bryan D. Jones. 2009. Agendas and instability in American politics. 2nd ed. Chicago, IL: Chicago University Press.

Becher, Tony, and Maurice Kogan. 1992. Process and structure in higher education. 2nd ed. London and New York, NY: Routledge.

Biesta, Gert. 2010. Five theses on complexity reduction and its politics. In Complexity theory and the politics of education, ed. D. Osberg and G. Biesta, 5-13. Rotterdam: Sense Publishers.

Biesta, Gert, and Deborah Osberg. 2010. Complexity, education and politics from the inside-out and the outside-in: An introduction. In Complexity Theory and the Politics of Education, ed. D. Osberg and G. Biesta, 1-4. Rotterdam: Sense Publishers.

Bird, R. 1994. Reflections of the British government and higher education. Higher Education Quarterly 48, no. 2: 73-85. 
Bleiklie, Ivar, Roar Høstaker, and Agnete Vabø. 2000. Policy and practice in higher education. Reforming Norwegian universities. Higher Education Policy Series 49. London: Jessica Kingsley.

Capano, G. 2009. Understanding policy change as an epistemological and theoretical problem. Journal of Comparative Policy Analysis 11, no. 1: 7-31.

Capps, E, T.E. Page, and W.H.D. Rouse, eds. 1918. Greek anthology V. New York, NY: G.P. Putnam's sons.

Castaldi, Carolina, and Giovanni Dosi. 2006. The grip of history and the scope for novelty: some results and open questions on path dependence in economic processes. In Understanding change. Models, methodologies, and metaphors, ed. Wimmer Andreas and Kössler Reinhart, 99-128. Houndmills: Palgrave Macmillan.

Cilliers, Paul. 2010. Acknowledging complexity. A foreword. In Complexity Theory and the Politics of Education, ed. D. Osberg and G. Biesta, vii-viii. Rotterdam: Sense Publishers.

Corbett, Anne. 2005. Universities and the Europe of knowledge. Ideas, institutions and policy entrepreneurship in European Union higher education policy, 1955-2005. Basingstoke: Palgrave Macmillan.

Edwards, D.B. 2012. Researching international processes of education policy formation: conceptual and methodological considerations. Research in Comparative and International Education 7, no. 2: 127-45.

Edwards, Richard. 2010. Complex global problems, simple lifelong learning solutions. Discuss. In Complexity Theory and the Politics of Education, ed. D. Osberg and G. Biesta, 69-78. Rotterdam: Sense Publishers.

Emirbayer, M. 1997. Manifesto for a relational sociology. American Journal of Sociology 103, no. 2: 281-317.

Fenwick, Tara. 2010. Normalising standards in educational complexity. A network analysis. In Complexity Theory and the Politics of Education, ed. D. Osberg and G. Biesta, 57-67. Rotterdam: Sense Publishers.

Government Programme. 2007. Government programme of Prime Minister Matti Vanhanen's second cabinet. 19 April 2007. Helsinki: Prime Minister's Office.

I'Anson, John. 2010. After rhetorics of neutrality: Complexity reduction and cultural difference. In Complexity Theory and the Politics of Education, ed. D. Osberg and G. Biesta, 121-34. Rotterdam: Sense Publishers.

Immonen, Kari. 1995. Suomen Akatemia suomalaisessa tiedepolitiikassa 1970-luvulla [The Academy of Finland in the Finnish Research politics in the 1970s]. Helsinki: Otava.

Kauko, Jaakko. 2011a. Korkeakoulupolitiikan dynamiikat Suomessa [Dynamics of Higher Education Politics in Finland]. Helsinki: University of Helsinki, Department of Behavioural Sciences.

Kauko, Jaakko. 2011b. Korkeakoulupolitiikan dynamiikat Suomessa [Lectio Praecursoria]. Tieteessä tapahtuu 29, no. 8: 25-30.

Kauko, Jaakko. 2013. Dynamics in higher education politics - a theoretical model. Higher Education 65, no. 2: 193-206.

Kauko, Jaakko, and Sara Diogo. 2011. Comparing higher education reforms in Finland and Portugal: different contexts, same solutions? Higher education management and policy 23, no. 3: 115-33.

Kauko, Jaakko, Hannu Simola, Janne Varjo, and Mira Kalalahti. 2012. What could a dynamics perspective contribute to comparative research? In Koulutuksen yhteiskunnallinen ymmärrys. Social Perspectives on Education, ed. J. Kivirauma, A. Jauhianen, P. Seppänen and T. Kaunisto, 219-33, Research in Educational Sciences 59. Turku: Finnish Educational Research Association.

Kauppa- ja teollisuusministeriö [Ministry of Trade and Industry]. 2006. Kauppa- ja teollisuusministeriön hallinnonalan tulevaisuuskatsaus 2006 [The future outlook for the sector of the ministry of Trade and Industry]. KTM julkaisuja 40/2006. Helsinki: Kauppa- ja teollisuusministeriö.

Kiel, L.Douglas 2006. Chaos in social systems: assessment and relevance. In Understanding Change. Models, Methodologies, and Metaphors, ed. A. Wimmer and R. Kössler, 51-58. Houndmills: Palgrave Macmillan.

Kingdon, John W. 2003. Agendas, Alternatives, and Public Policies. 2nd ed. New York: Longman. 
Kivinen, Osmo, and Risto Rinne. 1992. Investment in higher education: the Finnish experience. Higher Education Policy 5, no. 2: 50-54.

Kivinen, Osmo, Risto Rinne, and Kimmo Ketonen. 1993. Yliopiston huomen [The future of the university]. Helsinki: Hanki ja Jää.

Kivinen, Osmo, Risto Rinne, and Jarmo Mäntyvaara. 1990. Muuttuva yliopisto korkeakoulupolitiikan tekijöiden näkemänä. Koulutussosiologian tutkimusyksikkö. Tutkimusraportteja 3. Turku: Turun yliopisto.

Knill, C, and A. Lenschow. 2001. "Seek and ye shall find!" Linking different perspectives on institutional change. Comparative Political Studies 34, no. 2: 187-215.

Kogan, Maurice, and Stephen Hanney. 2000. Reforming Higher Education. Higher Education Policy. 50. London: Jessica Kingsley.

Ma, S.-Y. 2007. Political science at the edge of chaos? The paradigmatic implications of historical institutionalism. International Political Science Review 28, no. 1: 57-78.

Medd, W. 2002. Complexity and the social world. International Journal of Social Research Methodology 5, no. 1: 71-81.

Meyer, Hans-Dieter. 2011. Path dependence in German and American public education- the persistence of institutional difference in a globalizing world. In Education Policy. Power and Process, ed. D.E. Mitchell, R.L. Crowson and D. Shipps, 189-212. New York, NY: Routledge.

Michelsen, Karl-Erik. 1990. Unelmana innovaatio. Teknologia ja tekninen tutkimus Suomessa 1972-1942 [A dream of innovation: technology and technical research in Finland 19721942] Unpublished licenciate work. University of Helsinki, Department of History.

Miettinen, Reijo. 2002. National Innovation System. Scientific Concept or Political Rhetoric. Helsinki: Edita.

Opetusministeriö [Ministry of Education]. 1989. Koulutuksen kehittämissuunnitelmatyöryhmän muistio [A memo by the working group on the development plan]. Opetusministeriön työryhmien muistioita 1989:1. Helsinki: Opetusministeriö.

Opetusministeriö [Ministry of Education]. 1998. Koulutus ja tutkimus vuosina. Kehittämissuunnitelma [Education and research 1999-2004. Development plan], 19992004. Helsinki: Opetusministeriö.

Opetusministeriö [Ministry of Education]. 2006. Valtioneuvoston koulutuspoliittinen selonteko eduskunnalle [The Government's report on education politics to parliament]. Opetusministeriön julkaisuja 2006:24. Helsinki: Opetusministeriö, Koulutus- ja tiedepolitiikan osasto.

Opetusministeriö [Ministry of Education]. 2007. Koulutus ja tutkimus vuosina. Kehittämissuunnitelma [Education and research 2007-2012. Development plan], 20072012. Opetusministeriö: Helsinki.

Opetusministeriö [Ministry of Education]. 2008. Korkeakoulujen rakenteellisen kehittämisen suuntaviivat vuosille 2008-2011 [Guidelines for structural development]. Helsinki: Opetusministeriö.

Osberg, Deborah. 2010. Taking care of the future? The complex responsibility of education \& politics. In Complexity Theory and the Politics of Education, ed. D. Osberg and G. Biesta, 153-66. Rotterdam: Sense Publishers.

Palonen, Kari. 1993. Introduction. In Reading the Political, ed. K. Palonen and T. Parvikko. Helsinki: Finnish Political Science Association.

Palonen, K. 2003. Four times of politics: Policy, polity, politicking, and politicization. Alternatives 28, no. 2: 171-86.

Palonen, Kari. 2006. The struggle with time. A conceptual history of 'politics' as an activity. Hamburg: Verlag Münster.

Parliamentary Committee for Constitutional Law. 2009. Perustuslakivaliokunnan lausunto 11/ 2009 [A statement by the Parliamentary Committee for Constitutional Law 11/2009].

Pernaa, Ville. 2007. Sivistyspolitiikan suurjärjestelmien rakentaminen. In Sivistyksen ja tiedon Suomi. Suomen eduskunta 100 vuotta, ed. V. Pernaa and A. Tiitta, 9-144. Helsinki: Edita.

Pierson, P. 2000. Increasing returns, path dependence, and the study of politics. The American Political Science Review 94, no. 2: 251-67.

Prigogine, Ilya. 1997. The end of certainty. Time, chaos, and the new laws of nature. New York, NY: Free Press.

Rancière, Jacques. 2010. Dissensus. Politics and aesthetics. London: Continuum. 
Rasmussen, Jens. 2010. Increasing complexity by reducing complexity. A Luhmannian approach to learning. In Complexity Theory and the Politics of Education, ed. D. Osberg and G. Biesta, 15-24. Rotterdam: Sense Publishers.

Richardson, Richard.C. Jr, Kathy Reeves Bracco, Patrick M. Callan, and Joni E. Finney. 1999. Designing state higher education systems for a new century. Phoenix, AZ: The Oryx Press.

Sabatier, P.A. 1987. Knowledge, policy-oriented learning, and policy change. An advocacy coalition framework. Knowledge: Creation, Diffusion, Utilization 8, no. 4: 649-92.

Sabatier, Paul A. 1993. Policy change over a decade or more. In Policy Change and Learning. An Advocacy Coalition Approach, ed. P.A. Sabatier and H.C. Jenkins-Smith, 13-39. Boulder, CO: Westview Press.

Schriewer, J. 2000. World system and interrelationship networks. The internationalization of education and the role of comparative inquiry. In Educational knowledge. Changing relationships between the state, civil society, and the educational community ed. T.S. Popkewitz, 305-43. Albany, NY: State University of New York.

Simola, H. 1995. Paljon vartijat. Suomalainen kansanopettaja valtiollisessa kouludiskurssissa 1860-luvulta 1990-luvulle. [The guards of plenty. The Finnish school teacher in state educational discourse from the 1860s to the 1990s]. Helsinki: University of Helsinki, Department of Teacher Education.

Simola, H. 2011. Towards comparative analytics of dynamics in education politics. A paper presented in an open seminar of the SCAS, the Swedish Collegium for Advanced Study, October 13, 2011, Uppsala.

Suomen Akatemia [The Academy of Finland]. 2009. Suomen tieteen tila ja taso [The state and level of Finnish research]. In Suomen Akatemian julkaisuja 9/09, ed. P. Löppönen, A. Lehvo, K. Vaahtera and A. Nuutinen. Helsinki: Suomen Akatemia.

Tiitta, A. 2004. Suomen Akatemian historia I. Huippuyksilöitä ja toimikuntia [The history of the Academy of Finland I, 1948-1969], 1948-1969. Helsinki: SKS.

Työ- ja elinkeinoministeriö [Ministry of Employment and Economy]. 2008. Kansallinen innovaatiostrategia [National innovation strategy]. Helsinki: Työ- ja elinkeinoministeriö.

Ursin, J, J. Välimaa, and H. Aittola. 2010. Towards joint educational structures and practices. Experiences from the mergers of Finnish universities. Paper presented in the EERA-conference, August 25, 2010, Helsinki.

Ursin, Jani, Jussi Välimaa, and Helena Aittola. 2011. Yliopistot yhdistyvät - muuttuuko koulutus? [Universities are merging - is education changing?]. In Koulutuspolitiikan käytännöt kansallisessa ja ylikansallisessa kehyksessä, ed. R. Rinne, A. Jauhiainen, J. Tähtinen and M. Broberg, 125-44. Turku: Finnish Educational Research Association.

Välimaa, Jussi. 2001. A historical introduction to Finnish higher education. In Finnish higher education in transition. Perspectives on massification and globalisation, ed. J. Välimaa, 13-53. Jyväskylä: Institute for Education Research, University of Jyväskylä.

Välimaa, Jussi. 2012. The corporatization of national universities in Finland. In Universities and the public sphere: Knowledge creation and state building in the era of globalization, ed. B. Pusser, K. Kempner, S. Marginson and I. Ordorika, 101-20. New York, NY: Routledge.

Valtioneuvosto [The Finnish Government]. 2004. Hallituksen strategia-asiakirja 2004. Hallituksen poikkihallinnolliset politiikkaohjelmat ja politiikat. Valtioneuvoston kanslian julkaisusarja 11/2004. Helsinki: Valtioneuvoston kanslia.

Valtion tiede- ja teknologianeuvosto [Science and Technology Council]. 1987. Tiede- ja teknologiapoliittinen katsaus 1987. Helsinki: Valtion tiede- ja teknologianeuvosto.

Valtion tiede- ja teknologianeuvosto [Science and Technology Council]. 1990. Katsaus 1990. Tiede- ja teknologiapolitiikan suuntaviivat 1990-luvulla. Helsinki: Valtion painatuskeskus.

Valtion tiede- ja teknologianeuvosto [Science and Technology Council]. 1993. Tiedon ja osaamisen Suomi. Kehittämisstrategia. Helsinki: Valtion tiede- ja teknologianeuvosto.

Valtion tiede- ja teknologianeuvosto [Science and Technology Council]. 1996. Suomi: tiedon ja osaamisen yhteiskunta. Helsinki: Valtion tiede- ja teknologianeuvosto.

Valtion tiede- ja teknologianeuvosto [Science and Technology Council]. 2000. Katsaus 2000: Tiedon ja osaamisen haasteet. Helsinki: Valtion tiede- ja teknologianeuvosto.

Valtion tiede- ja teknologianeuvosto [Science and Technology Council]. 2003. Osaaminen, innovaatiot ja kansainvälistyminen. Helsinki: Valtion tiede- ja teknologianeuvosto. 
Vanttaja, Markku, and Kimmo Ketonen. 1995. Korkeakoululaitoksen rakenteellinen kehittäminen. Tapaustutkimus lääketieteen ja kasvatustieteen koulutusaloilta. Koulutussosiologian tutkimuskeskuksen raportteja 28. Turku: Turun yliopisto.

Weick, Karl E., Kathleen M. Sutcliffe, and David Obstfeld. 2005. Organizing and the process of sensemaking. Organization Science. 16, no. 4: 409-21.

Wimmer, A. 2006. Models, methodologies, and metaphors on the move. In Understanding change. Models, methodologies, and metaphors, ed. Wimmer Andreas and Kössler Reinhart, 1-36. Houndmills: Palgrave Macmillan.

Yliopistolaki. 558/2009. [Finnish Universities Act], 24 July 2009. 